\title{
FIRST RECORD OF PTERIDOPHYTE DIVERSITY AT MOUNT MINGAN, GABALDON, NUEVA ECIJA, PHILIPPINES
}

\author{
Edwin Padilla Hererra Jr. ${ }^{1}$, Krystel Grace Vergara Padilla ${ }^{1}$, King Dave Gloria Martin ${ }^{1 *}$ \\ ${ }^{1 *}$ Nueva Ecija University of Science and Technology, Chemistry and Environmental Science Department, \\ College of Arts and Sciences, Cabanatuan City, Nueva Ecija, 3100, Philippines; \\ *Corresponding author King Dave Gloria Martin, e-mail: kgmartin@up.edu.ph;
}

Received August 2020; Accepted September 2020; Published October 2020;

DOI: https://doi.org/10.31407/ijees10.415

\begin{abstract}
Pteridophytes, commonly known as ferns, are vascular plants that bear spores which are widely distributed in tropical regions, specifically in humid, sheltered areas. Being neglected most of the time, some members of group are vulnerable and critically endangered. But these plants play a role in maintaining the balance in the ecosystem and could be potential source of economically important compounds. Mingan mountain is a part of Sierra Madre Range National Park and the knowledge of pteridophyte diversity in the area is poor. This study aimed to list the species and assess the diversity of pteridophytes at Mt. Mingan, Gabaldon, Nueva Ecija. Fourteen (14) species of pteridophytes, namely, Nephrolepis falcata, Pneumatopteris nitidula, Christella arida, Christella acuminata, Nephrolepis cordifolia, Microsorum scolopendria, Microlepia platyphylla, Microsorum membranifolium, Polystichum sp., Davallia solida, Orthiopteris campylura, Microsorum longissimum, Pteris oppositipinnata, and Drynaria descensa were identified to be present at Mt. Mingan. One species, Microsorum scolopendria, was found to be vulnerable. In addition, Pneumatopteris nitidula, Drynaria descensa, Davallia solida and Pteris oppositipinnata were recorded to be endemic in the Philippines. Diversity indices state that diversity of pteridophytes at Mt. Mingan is low. Tree diversity in the sampling area was also found to be low by a related study. According to the barangay secretary of Brgy, South Poblacion, Gabalodon, incidents of timber poaching, charcoal production, and illegal logging were recorded in the site. Mentioned threat is one of the possible reasons for low diversity of pteridophytes in Mt. Mingan.
\end{abstract}

Keywords: Pteridophytes, Fern, Mount Mingan, Biodiversity, Illegal logging 